\title{
〔第18回秋季学術大会シンポジウム 一ディジタルラジオグラフィの画像評価一〕
}

\section{2. 入出力特性}

坂 本清

兵庫医科大学病院中央放射線部

Key words : Digital radiography, Digital subtraction angiography, Computed radiography, Characteristic curve, Pixel value

\section{THE RELATIONSHIP BETWEEN INPUT AND OUTPUT IN DIGITAL RADIOGRAPHY}

\author{
KiYOSHI SAKAMOTO \\ Department of Radiology, Hyogo College of Medicine
}

\begin{abstract}
Summary
Characteristic curves are useful in the comparison of system speeds and in the linearization of the system response for measurement of the modulation transfer function and other physical quantities. The characteristic curve of a digital radiographic imaging system can be defined as the relationship of the output in terms of pixel value to the input in terms of relative $\mathrm{x}$-ray intensity. Several different methods for determining the characteristic curve of digital radiography systems are available. We used four methods and two methods in order to determine the characteristic curve of digital subtraction angiography system (DSA) and computed radiography (CR) system. Because luminous intensity increases in proportion to X-ray intensity in these systems, we could use the time-scale method. We had to choose most suitable method in DSA system. In CR system, we can treat in a way similar to that of a screen-film system.
\end{abstract}

\section{1.はじめに}

ディジタルラジオグラフィの画像評価を行う場合，入 出力特性としての特性曲線を測定することは重要である. Fujitaらは，ディジタルシステムの入出力特性を測定 し ${ }^{1-3)}$ ，特性曲線と定義している. 本会の専門委員会では 「ディジタル画像の物理的評価検討班」発足し，ディジ タルラジオグラフィの画像評洒について検討を行ってい る.ここでは，主に第一期のメンバーによって検討され た「ディジタルラジオグラフィの特性曲線の测定 ${ }^{4)} 」$ の 容を中心に述べる。ディジタルラジオグラフィはDSA (Digital Subtraction Angiography) と CR (Computed Ragiography) に代表されるが，ディジタル特性曲線を
測定するには以下に示す測定法が考えられる。

\section{DSA の特性曲線}

DSA システムでは，I.I.に入射するX線強度を制御す る方法と, TVカメラに入射する监光量を制御する方法 がある.X線強度を制御する方法には，(1)アルミニウム をX線減弱物質として用いI.I.へ入射するX線強度をア ルミニウムの厚さにより変化させるアルミニウム法, (2) X線管と I.I. との距離を変化させ入射X線強度を変化さ せる距離法, (3)装置の夕イマを変化させる夕イムスケー ル法があり，蛍光量を制御する方法には，(4)二ュートラ ルデンシティ（N.D.）フィルタを使用し，TVカメラヘ の入射光量を変化させる N.D. フィルタ法, (5)アイリス 
を変化させる方法，が考えられる．これらの方法はそれ ぞれ問題点があり, 装置によっては不可能な場合もある. ここでは(1)一(4)について述べる.

\section{1 アルミニウム法}

藤田らの報告によれば，Cronex Quanta III（デュポン 社製) はイメージインテンシファイア (I.I.) の入力蛍光 面の蛍光体 (CSI) と同等のX線吸収特性を示すため, こ の増感紙を I.I. に代用させることができる1).アルミニウ ムをX線減弱物質として用い, I.I. 入入射するX線強度 をアルミニウムの厚さにより変化させる方法である5). アルミニウムの厭みを X線強度に変換する必要があるが, マニュアル撮影のできない装置にも使用できるので有用 である。まず,距離法により,Quanta IIIを用いた増感紙/ フィルムシステムの特性曲線を作成する。次にアルミニ ウムステップの撮影を行い, 各ステップの写真濃度をX 線強度に変換する．これはアルミニウムの減弱曲線に相 当する.さらにDSA 装置を用いて同条件下でアルミニ ウムステップの撮影を行い，各ステップのピクセル值を 読み取り，アルミニウム厚をピクセル值に置き換える。 これでディジタル特性曲線が完成する。

\subsection{N.D.フィルタ法}

これは, N.D. フィルタ（コダック ラッテン ニュー トラルデンシティ フィルタ No.96）を用いて，X線 TVに入射するI.I. の 2 次蛍光面の光強度を制御する方 法である.I.I.に入射するX線強度と 2 次蛍光面の监光 量には直線関係が成り立つためこの方法が可能である.

このフィルタは約 $450 \mathrm{~nm}$ 以上の波長に対して透過率が 一定であり，X線 TV カメラに入射する光量 (平均波長 約530 nm）を変化させるのに適している，撮影条件は一 定にし，タンデムレンズ間に挿入するフィルタの濃度を 変化させて, X 線 TV カメラに入射する光量を制御す る.このときのフィルタの濃度（透過光量）と撮影され た画像のディジタル值との関係が特性曲線となる.

\section{3 距 離 法}

距離法については，本会の「X線センシトメトリ班」 において, 方法, 精度などが十分検討されており ${ }^{6)}$, 増感 紙/フィルム系の特性曲線作成法は距離法が一般的とな っている.しかし, DSA システムの場合, 装置によって は移動可能な距離が制限されるため，どの装置でも可能 というものではないし，マニュアル撮影ができない装置 では困難である。

\section{4 タイムスケール法}

I.I.には相反則不軌が生じないため夕イムスケール法 が使用できる点が見逃せない.マニュアル撮影ができる
装置では，装置の撮影タイマが使用できるため簡便で有 効である.

\section{5 結 果}

$60 \mathrm{kV}, 90 \mathrm{kV}$ で測定した,アルミニウムの減弱曲線を

Fig. 1 に示す.この減弱曲線を用いてアルミニウム厚を X線強度に変換した，アルミニウム法の特性曲線を Fig. 2 に示す． 2 つの電圧で測定した特性曲線は形状を比較 するために平行移動して表示してある.Fig. 1, Fig. 2, Fig. 5 は DFP-50A (東芝) を用いた大西氏によるデータ である，異なる管電压で测定した特性曲線も，同じ形状 を示すことから，DSA 装置の特性曲線は I.I.に入射する X線の線質に依存しないといえる。

$\mathrm{X}$ 線強度と蛍光量の関係を Fig. 3 飞示す, 照度計 (MAVO-MONITOR) を用い，X線管焦点一I.I. 間の距

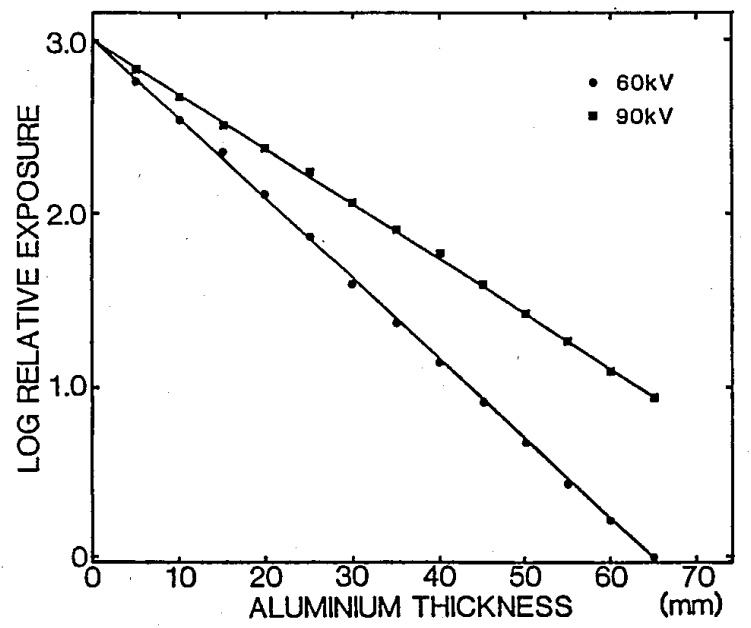

Fig. 1 Relationship between relative $x$-ray intensity and aluminum thickness. It was determined with a Cronex QuantaIII/Rx screen-film combination.

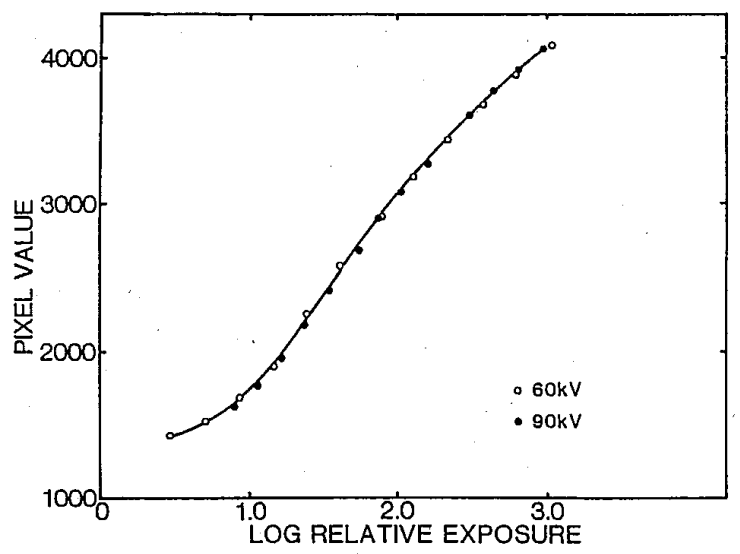

Fig. 2 Characteristic curves relating the pixel value to the $\mathrm{x}$-ray intensity using aluminum method on DSA system. The $\mathrm{x}$-ray exposures were made at 60 and $90 \mathrm{kV}$. 
離を変えることによりX線強度を変化させ，I.I.の 2 次 蛍光面の蛍光量を測定したものである．照射野のサイズ $(2 \times 2 \mathrm{~cm}, 5 \mathrm{~cm} \phi)$ によりグラフの傾きは変化するが, $\mathrm{X}$ 線強度と䖢光量は直線関係が成り立っているのが分か る. 次に, N.D.フィルタ法により测定した特性曲線を Fig. 4 に示す.使用した装置はディジトロン一-3 (シーメ ンス), 撮影条件は $63 \mathrm{kV}, 512 \times 512$ マトリックス, 10 ビ ットである.この装置では Fig. 2 の特性曲線と比較し て, 曲線の傾きが逆である点, ディジタル值が 0 となる 線量以上の強度を与えると再び值が現われる点などが特 徵といえる。

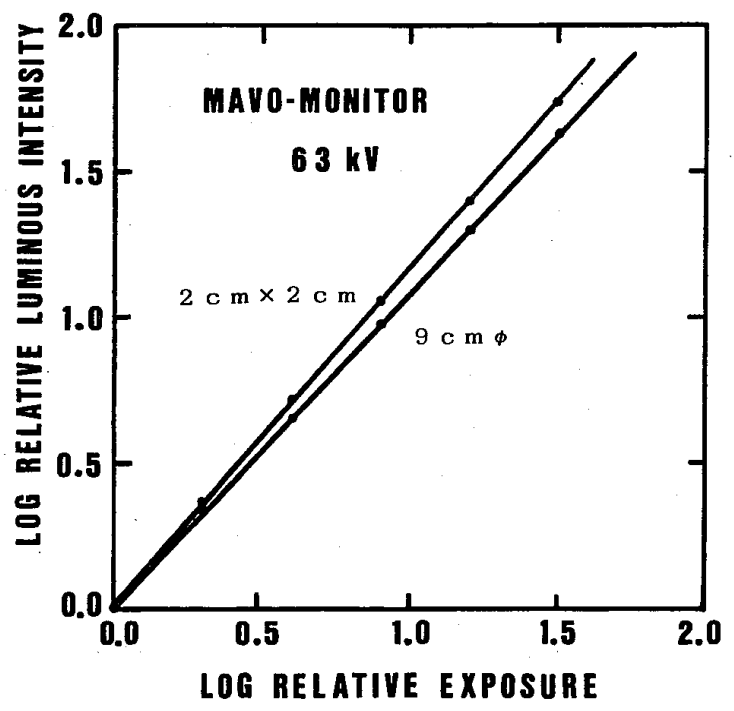

Fig. 3 Relationship between luminous intensity and relative $\mathrm{x}$-ray intensity of imageintensifier. It was measured by using luminous meter with inverse square method.

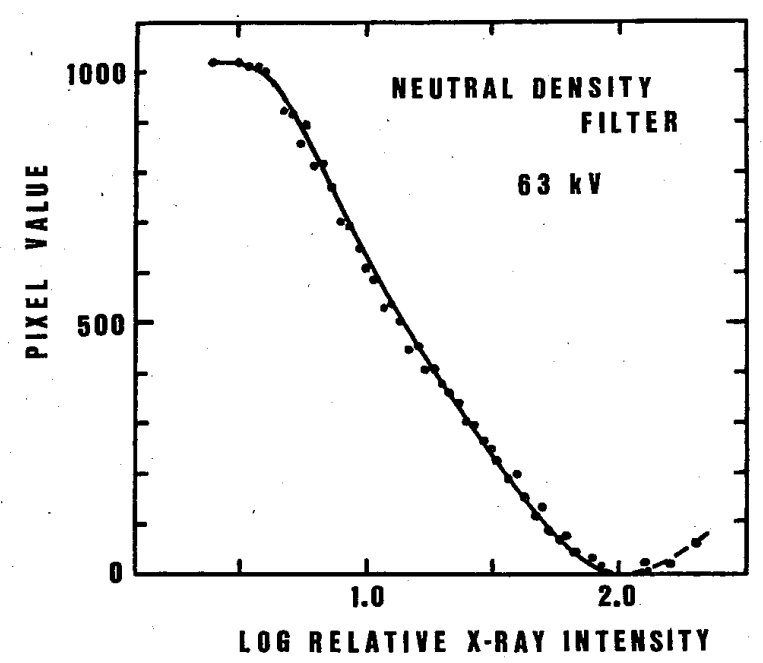

Fig. 4 Characteristic curve of DSA system measured by using neutral density filter method.
また，大西氏は N.D.フィルタ法で，画像収集速度およ びX線パルス幅の影響についても検討を行っており,「マ トリックスサイズが同じであれば，撮影モードが変化し ても特性曲線の変化はない.マトリックスサイズが変わ ればダイナミックレンジが変わる，画像収集速度を遅く すると曲線の勾配が緩やかになるが，X線パルス幅の影 響は受けない.」と報告している。画像収集速度による影 響は, 撮㑇管の走查方式(インタレース/プログレッシブ) が変わるためであろう. 距離法, N.D.フィル夕法の特性 曲線はよく一致している（Fig.5).

Fig. 6 に蛍光量計を用いて测定した，設定時間と露光 量との関係を示す.これは CR のタイムスケール法で用 いたものであるが，タイムスケール法を行う場合，タイ マ精度を調べておく必要がある。

どの方法をとるにしても, 開口空寸法を極力小さくし

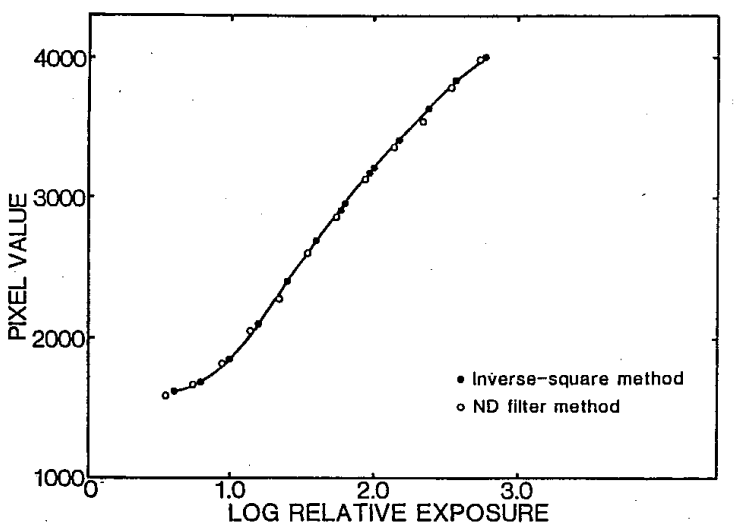

Fig. 5 Comparison of characteristic curves measured by using neutral density filter method and inverse square method on a DSA system.

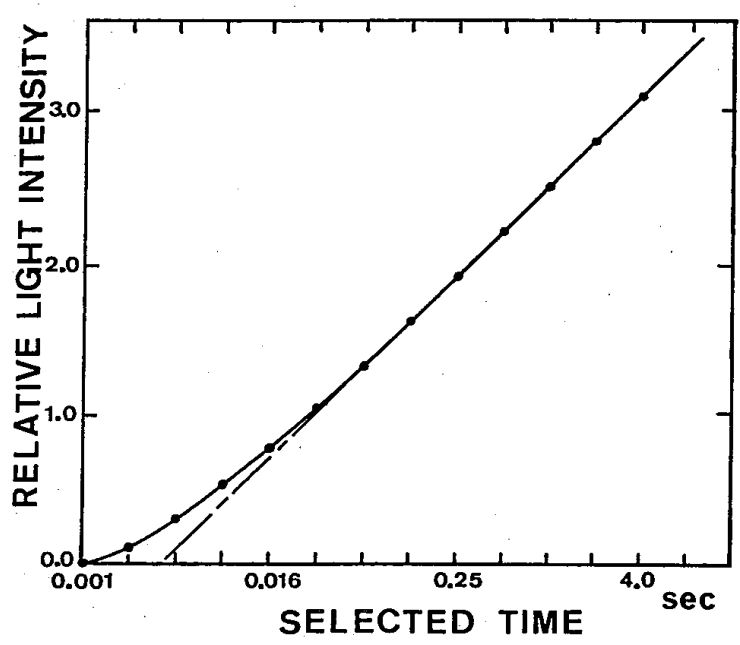

Fig. 6 Relationship between fluorecent intensity to selected time measured by using fluorecence meter. 
て，散乱線，I.I.のベーリンググレア（VG）の影響を隇 少させなければならない.アルミニウム法では拡大撮影 を行い，グレーデル効果を利用することも有効である。

\section{CR の特性曲線}

CR では増感紙/フィルム系と同じ扱いができるため 増感紙/フィルム系で一般的となっている(1)距離法を参 考にすれば良い.しかし，CR システムでは，検出器とし てフィルムが用いられていないため相反則不軌が起こら ず，発生器のタイマを用いた(2)夕イムスケール法が使用 できる点が見逃せない。ここで使用した FCR101 は，シ ステム感度を $\mathrm{E}$ 值, ダイナミックレンジを $\mathrm{L}$ 值 $\left(\mathrm{LOG}_{10} \mathrm{E}\right.$ に対応）で表示している.イメージングプレート (IP) は標準タイプのSTを用いた。

\section{1 距 離 法}

DSA システムのところでも述べたように，増感紙/フ イルム系の特性曲線作成法は睡に確立されており，CR の特性曲線作成にも応用することができる7).ここでは， 焦点-IP 間距離は，比露光量が 2 倍になるように40.1$320 \mathrm{~cm}$ の間を移動させ， 7 点で測定した.この条件で は, 比露光量が64倍であり, IP のX線受光可能域 $10^{4}$ 倍を カバーするために，X線発生装置の夕イマを 3 段階に変 化させた（Fig. 7).

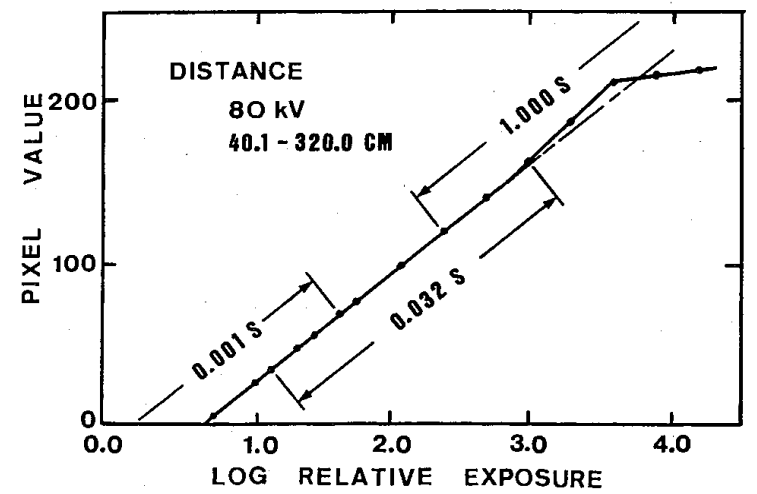

Fig. 7 The technique for measuring charactristic curve of computed radiography by using inverse square method.

装置の収録モードは，特性曲線の形状を詳しく見るた めに，L值を最大 $(\mathrm{L}=3.6)$ とした．また，照射線量の 影響をみるために; $\mathrm{E}$ 值を40 (大線量用), 400 (中線量 用)，および 4000 (小線量用) とした.さらに，線質の影 響をみるために,一般に使用されている $80 \mathrm{kV}$, 軟線質用 の30 kV，硬線質用の $120 \mathrm{kV}$ で検討した。また，照射線 量確認のための線量測定は, IONEX（0.3 cc Shallow
Chamber）を用いて行った。

\section{2 タイムスケール法}

DSA システムと同様, 相反則不軌が生じないため有効 な方法である8). タイムスケール法について，タイマ使用 による種々の問題を解決するため，蛍光量計を用いて测 定し（Fig. 6)，装置のタイマの各々の設定值 (0.001 8.0 sec）と露光量の校正をした。

\section{3 結 果}

1 枚の IP に数力所露光した場合の CR 画像を Fig. 8 に示すＩP からの読み取りには He-Ne レーザービーム が使用され, 輝尽発光の発光寿命は $0.8 \mu \mathrm{sec}$ と非常に短 いとされている.しかし, Fig. 8 に示したように, 極端な 露光を与えた場合には影響があるため，読み取りレーザ ービームの走查方向を考慮して露光位置を決める必要が ある.

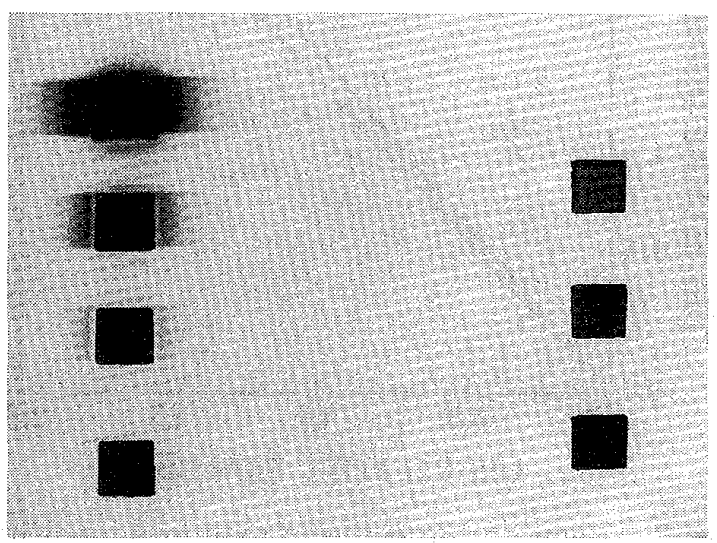

Fig. 8 Image of computed radiography used for measuring of characteristic curve.

距離法を適用して測定したCR の特性曲線を Fig. 9,

Fig. 10 に示す。ここでは, 形状を比較するために，横軸 を平行移動させて表示している. 本装置の場合, IPから 読み取られた信号は 8 ビットのディジタル值（ピクセル 值）に $\mathrm{A} / \mathrm{D}$ 変換されるため，特性曲線の縦軸は $0 \sim 255$ で示される.IPの線量依存性は直線関係にあると言われ ているが, CR システムで読み取った場合, 線量の多少に かかわらず，ピクセル值（０-255）が150-170で傾きが大 きくなり，さらにピクセル值の大きいところ（210-230） で急激に傾きが小さくなった。傾く位置は $\mathrm{E}$ 值に依存し ているようである.ピクセル值の小さいところでは直線 であるが $\mathrm{E}$ 值が大さい場合で線量が少なくなると，フィ ルムの特性曲線の足部のように，直線性を失った。 $\mathrm{E}$ 值 が等しいとき，30，80, $120 \mathrm{kV}$ 共に同じ曲線となり，管 電圧の違いによる特性曲線の形状に変化はなかった。

Fig. 11 はE值を200一定とし, L值を変化させた結果で, 


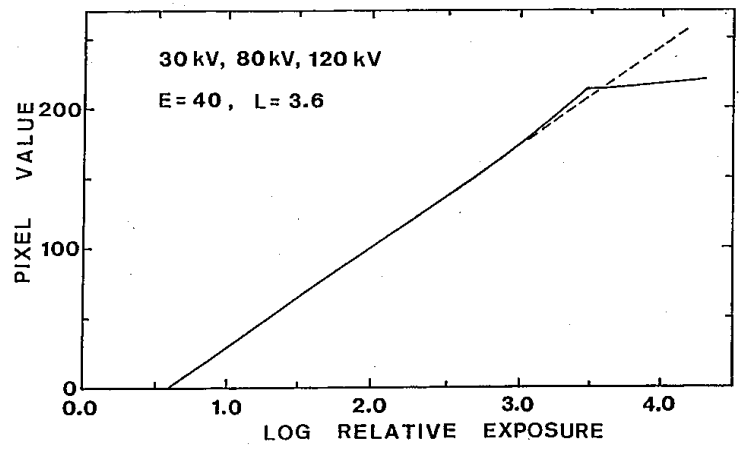

Fig. 9 Comparison of characteristic curves for three different $\mathrm{kV}$ measured by using inverse square method on a computed radiography system.

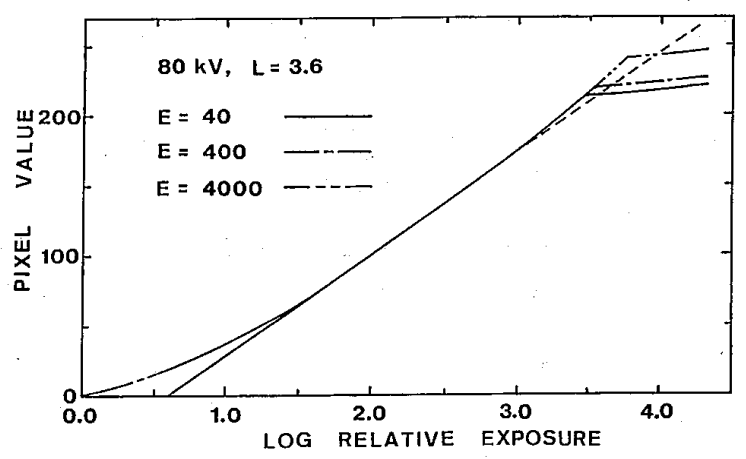

Fig. 10 Comparison of characteristic curves for different settings of $E$ value measured by using inverse square method on a computed radiography system.

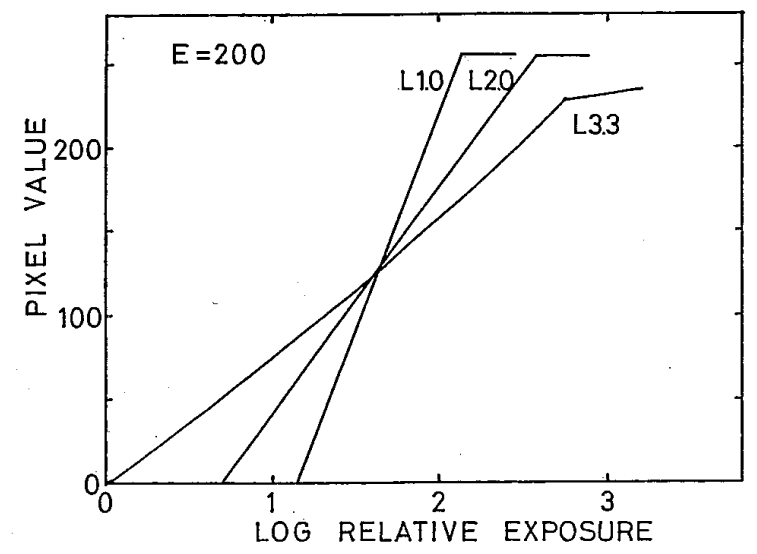

Fig. 11 Comparison of characteristic curves for different settings of $L$ value measured by using inverse square method on a computed radiography system.

杜下氏によるものである.どのL值でも増感紙/フィルム に比べて直線性が良い，L值が1.0，2.0ではピクセル值 が255で飽和して一定值になっている，L值が3.3では， ピクセル值は255まで達せず，230付近で飽和する傾向に

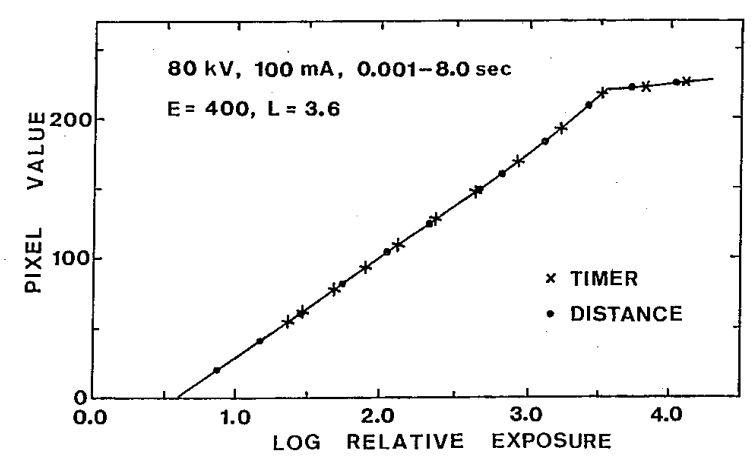

Fig. 12 Comparison of characteristic curves measured by using time scale method and inverse square method on a computed radiography system.

ある。また，X線発生装置のタイマを利用した方法につ いても，距離法と同じ形状となった(Fig. 12)。このとき の設定時間と蛍光量計で測定した露光量との関係は Fig. 6 に示している.

\section{4. ま と め}

DSA およびCR システムでは相反則不軌が生じない ため，タイムスケール法が採用できるという利点がある が，タイマ精度を確認する必要があるし，DSA システム では，マニュアル撮影ができない装置もあり, 装置に適 した方法をとる必要がある。

\subsection{DSA システムの特性曲線}

どの方法をとるにしても，開口空寸法を極力小さくし て, 散乱線, I.I.のVG の影響を減少させなければならな い.アルミニウム法では搪大撮影を行い, グレーデル効 果を利用することも有効である．また，アルミニウム法 は間接法であり，多くの測定系を通過するため実験誤差 が大きくなる可能性があるので十分な注意が必要である. N.D. フィルタ法ではX線 TV カメラの入射光量を変化 させているので，I.I. 肪よび光学レンズ系の特性が合ま れていない。また，一般にタンデムレンズにはフォトマ ルの受光部が設置されているため，アイリスサイズの選 択に注意する必要がある。堀田氏は乳房専用撮影装置 (DFP-50A 特, 東芝) の軟X専用 I.I. の特性曲線を, N. D. フィルタ法により測定し, 本装置の入出力特性はリニ アであると報告している. N.D.フィル夕法は, 多くの装 置に適用できる反面，フィルタ交換の度に電源を切る必 要があり，手間がかかる.

\section{$4.2 \mathrm{CR}$ の特性曲線}

$\mathrm{CR}$ の特性曲線で，ピクセル值の大きいところの傾き の変化は，極端に強い入力光量を受けた場合の防止のた 
めに，人為的に行っているものと考える．E值が大きい ときの足部での非直線性は， $\mathrm{E}$ 值を設定する時点でフォ トマルの印加電圧を設定するため， $\mathrm{E}$ 值が大きいとフォ トマルの印加電圧が高くなり, 暗電流の影響を受け, IP の発光強度とフォトマル電流量の直線性がなくなるもの と思われる。

CR の特性曲線作成においても，距離法が適用できた。 $\mathrm{X}$ 線発生装置のタイマを利用したタイムスケール法につ いても，距離法と同じ結果が得られ，測定が簡便である. また，管電圧を変えても特性曲線の形状に変化はなかっ た. IP のフェーディングは 8 時間で $25 \%$ 程度といわれて いたが New TypeのIPでは20分で20\%という千田らの 報告9ももり，扱いに注意を要する。また，自然放射線， 残像の影響を考えて，使用前に十分画像を消去するべき である。

最後に, 第一期「ディジタル画像の物理評価検討班」 班長の岐阜工業高等専門学校電気工学科の藤田広志先生, 班員の国立循環器病センター放射線診断部の大西義隆氏, 愛知県がんセンター病院放射線診断部の堀田勝平氏，山 口大学医学部付属病院放射線部の杜下淳次氏に感謝致し ます。

\section{文 献}

1) Fujita H. Doi K. Giger ML, et al. : Investigation of basic imaging properties in digital radiography. 5. Characteristic curves of II-TV digital systems. Med. Phys., 13, 13-18, (1986).

2）藤田広志，土井邦雄：I.I./TV ディジタル撮像系の 特性曲線の測定. 医画情誌，4，31 35，（1987）。

3) Fujita $H$ and Doi $K$ : Accurate measurements of characteristic curves of II-TV digital systems by use of aluminum stepwedge technique. Med. Phys., 13, 922-924, (1986).

4）藤田広志，大西義隆，坂本 清，他：ディジタルラ ジオグラフィの画像評価１１．特性曲線，日放技学 誌，46，1579-1592，(1990）（委員会報告).

5）金井一美, 大塚昭義，杜下淳次，他：DSA システム の特性曲線一測定法の比較一.日放技学誌, 44, 1492 -1496, (1988).

6）山本義憲, 粟井一夫, 大竹英則, 他：増感紙フィル ムシステムのX線センシトメトリーについて，日放 技学誌，40，59-78，(1984）（委員会報告）。

7）上田克彦, 杜下淳次, 藤川津義, 他：コンピューテ ッドラジオグラフィの特性曲線の測定 $(1)$ ．医画情 誌, 5, 52-59, (1988).

8）杜下淳次, 藤田広志, 坂本 清, 他：コンピューテ ッドラジオグラフィの特性曲線の測定 (II). 医画情 誌, 6, 25-33, (1989).

9）千田浩一, 有馬宏寧：イメージングプレートの比較 的短時間に扔けるフェーディング現象. 医画情誌， 7, 79-87, (1990). 